\title{
Transcriptomic Analysis of the White-rot Basidiomycete Lentinus Squarrosulus to Provide Insights Into Its Lignocellulose Biodegradation Ability
}

\author{
Aarthi Ravichandran \\ National Institute of Animal Nutrition and Physiology \\ Atul Kolte \\ National Institute of Animal Nutrition and Physiology \\ Arindam Dhali \\ National Institute of Animal Nutrition and Physiology \\ S Gopinath \\ Manpal Sridhar ( $\square$ manpalsridhar@yahoo.co.uk) \\ National Institute of Animal Nutrition and Physiology
}

\section{Research Article}

Keywords: Lentinus squarrosulus, biodegradation, transcriptome, lignocellulose

Posted Date: January 7th, 2022

DOI: https://doi.org/10.21203/rs.3.rs-1136812/v1

License: (c) (i) This work is licensed under a Creative Commons Attribution 4.0 International License.

Read Full License 


\section{Abstract}

\section{Background}

Basidiomycetes are of special interest in biotechnological research for their versatile potential in the degradation of lignocellulosic biomass, chiefly attributed to ligninolytic enzymes along with exo, endo $\beta$ glucanases, xylanases, esterases, pectinases, mannanases, cellobiohydrolases, polysaccharide monooxygenases. Relatively little is known about the metabolic process and the subsequent polysaccharide degradation. Transcriptomic analysis of lignicolous fungi grown on different substrates, although attempted by researchers, has focused on a fairly small group of species reporting the expression of fungal genes in response to lignocellulosic biomass as a substrate. This study accordingly reports analysis of transcriptome of a white-rot Basidiomycete L.squarrosulus grown in simple potato dextrose broth supplemented with aromatic compound, reactive black dye to gain an insight into the degradation ability of the fungus. RNA was sequenced using Illumina NextSeq 500 to obtain 6,679,162 high-quality paired-end reads that were assembled de novo using CLC assembly cells to generate 25,244 contigs. Putative functions were assigned for the 10,494 transcripts based on sequence similarities through BLAST2GO 5.2 and Function annotator.

Results

Functional assignments revealed enhanced oxidoreductase activity through the expression of diverse biomass-degrading enzymes and their corresponding coregulators. CAZyme analysis through dbCAN and CUPP revealed the presence of 6 families of polysaccharide lyases, 51 families of glycoside hydrolases, 23 families of glycoside transferases, 7 families of carbohydrate esterases and 10 families of auxiliary activities. Genes encoding ligninolytic enzymes and auxiliary activities among the transcript sequences were identified through gene prediction by AUGUSTUS and FGENESH. Biochemical analysis of several biomass-degrading enzymes substantiated the functional predictions.

\section{Conclusion}

In essence, L. squarrosulus grown in a simple medium devoid of lignocellulosic substrate demonstrated the presence of a repertoire of lignocellulose-degrading enzymes, simplying that a source of lignocellulose is not required for the expression of these biomass-degrading enzymes. This study on the transcriptome analysis of $L$. squarrosulus revealed significant facts on this front and will definitely enhance the knowledge about the biodegradative ability of this fungus, potentially paving the way for efficient biotechnological applications utilizing its potency in biomass degradation and its future functional exploitation in biomass conversion applications.

\section{Background}

Basidiomycetes have been the focus of intense research by mycologists for their antioxidant, antiparasitic, immune modulating effects and considerable biomass degradation [1]. The biodegradation 
of plant biomass, especially cellulose and hemicellulose, has been examined with different groups of Basidiomycetes; however, the distinctive ability of lignin depolymerization is an attribute of relatively few species. This group of basidiomycetous fungi commonly referred to as "white rot" is saprophytic on plant organic matter, and they acquire energy from plant polysaccharides cellulose and hemicellulose by disrupting the lignin complex, a refractory polymer cementing carbohydrates [2]. The biological and economic significance of lignin degradation is exemplified by the multifarious downstream applications of plant polysaccharides. White-rot fungi secrete ligninolytic enzymes for degrading lignin that include phenol oxidases such as laccases and peroxidases such as lignin peroxidase, manganese peroxidase and versatile peroxidase[3]. Ligninolytic enzymes bank upon $\mathrm{H}_{2} \mathrm{O}_{2}$-producing enzymes and other intermediate products of lignin degradation, which in turn serve as cofactors for further depolymerization. Enzymes involved in the decomposition of lignocelluloses by these fungi are not limited to ligninolytic enzymes but include exo, endo $\beta$-glucanases, xylanases, esterases, pectinases, mannanases, cellobiohydrolases, and polysaccharide monooxygenases. The production and expression of these enzymes is regulated chiefly by the environmental conditions and substrate of growth [4]. Having stated the complexity of lignocellulose degradation, relatively little is known about this metabolic process and the subsequent polysaccharide degradation. Hence, in this arena, transcriptomic analysis of lignicolous fungi grown on different substrates has been attempted by researchers worldwide to gain more insight into the degradation process [5-9]. Nevertheless, these studies have thus far focused on a fairly small group of species, and the expression of fungal genes in response to lignocellulosic biomass as a substrate has been reported. Our work on these lines aimed to delineate the expression of lignocellulosedegrading genes of $L$. squarrosulus grown in a simple medium devoid of lignocellulosic substrate. Lignocellulosic biomass is a complex network of polysaccharides cemented with lignin and hence induces the expression of a plethora of biomass-degrading enzymes in colonized white rot. To better understand the regulation of these enzymes on a nonlignocellulosic substrate, attempts were made to investigate the transcriptome of $L$. squarrosulus cultured in potato dextrose broth induced with reactive black 5 for ligninolytic enzymes. L. squarrosulus is a tropical white-rot fungus that grows immensely on decaying wood and saw dust. L. squarrosulus is a rich producer of ligninolytic enzymes predominantly versatile peroxidase, as identified through our study. Although complete depiction of the ligninolytic machinery is very far, transcriptomic analyses of this fungus grown in synthetic medium can add significant insights to the ligninolytic process.

\section{Methods}

\section{Fungal strain and culture conditions}

The fungus subjected in the study was a wild isolate from Western Ghats, India, determined through ITS sequencing. This isolate, identified as $L$. squarrosulus, was propagated through tissue culture and maintained by frequent subculturing on potato dextrose agar at $28^{\circ} \mathrm{C}$. The production of ligninolytic enzymes was induced by supplementing potato dextrose broth with $0.01 \%$ reactive black 5 (RB5), an azo dye. An Erlenmeyer flask with $50 \mathrm{ml}$ of culture medium was inoculated with homogenized mycelia at $2 \%$ 
from freshly grown seed culture of the fungus. The flasks were continuously agitated at $100 \mathrm{rpm}$ and incubated at $28 \pm 2{ }^{\circ} \mathrm{C}$ for seven days.

\section{Enzyme activity measurements}

L. squarrosulus cultivated in potato dextrose broth induced with RB5 for the production of ligninolytic enzymes was assessed for the existence of extracellular biomass-degrading enzymes. Extracellular biomass-degrading enzymes such as cellulase, xylanase, polygalacturonase, mannanase, a-glucosidase, $\beta$-glucosidase and xylan esterases were assayed in the culture supernatant in addition to the ligninolytic enzymes laccase, manganese peroxidase and versatile peroxidase. The culture supernatant was filtered to remove mycelia and utilized for biochemical assays.

Cellulase activity was deduced with carboxymethyl cellulase as the substrate. The assay mixture consisted of substrate $0.25 \%$ and $0.2 \mathrm{ml}$ culture supernatant in $50 \mathrm{mM}$ phosphate buffer $\mathrm{pH} 6.8$ [10]. The procedure for xylanase estimation is similar to cellulase, with the substrate being $0.06 \%$ oat spelt xylan. The polygalacturonase assay reaction mixture comprised $0.45 \%$ polygalacturonic acid and $0.1 \mathrm{ml}$ culture supernatant in $50 \mathrm{mM}$ acetate buffer at pH 5 [11]. Mannanase activity was inferred with $0.5 \%$ locust bean gum as the substrate. Then, $0.1 \mathrm{ml}$ of culture supernatant was reacted with $0.9 \mathrm{ml}$ substrate solution in phosphate buffer $\mathrm{pH} 6.8$ [12]. Reducing sugars produced through the enzyme reaction were measured by the dinitrosalicylic acid (DNS) method at $575 \mathrm{~nm}$ [13]. D-glucose, D-xylose, D-galacturonic acid and Dmannose were used as standards for the estimation of cellulase, xylanase, polygalacturonase and mannanase activities, respectively.

a-Glucosidase, $\beta$-glucosidase and xylan esterase activities were interpreted using $0.1 \% \mathrm{p}$-nitrophenol a-D glucopyranoside, $0.1 \% \mathrm{p}$-nitrophenol $\beta$-D glucopyranoside and $0.02 \% \mathrm{p}$-nitrophenol acetate as substrates, respectively, with p-nitrophenol as the standard $[10,14]$. The substrates were accordingly dissolved in 0.1 $\mathrm{M}$ phosphate buffer $\mathrm{pH} 6.8$ prior to use and reacted with $0.1 \mathrm{ml}$ of culture supernatant as a crude enzyme sample. Enzyme activity was determined by quantifying the amount of p-nitrophenol released from the reaction at $400 \mathrm{~nm}$.

A total of $1.6 \mathrm{mM}$ 2,2-azino-bis(3-ethylbenzothiazoline-6-sulfonate (ABTS) in $100 \mathrm{mM}$ sodium acetate buffer ( $\mathrm{pH} 4.5)$ was used to estimate laccase activity $\left(\mathrm{e}_{420} 36000 \mathrm{M}^{-1} \mathrm{~cm}^{-1}\right)$. Peroxidase interference with laccase activity was corrected using $0.5 \mu \mathrm{g} / \mathrm{ml}$ catalase in the reaction mixture. Manganese oxidation activity was deduced using $0.5 \mathrm{mM} \mathrm{MnSO}_{4}$ and $100 \mathrm{mM}$ malonate buffer $\mathrm{pH}$ 4.5. Formation of the $\mathrm{Mn}^{3+}$ malonate complex was measured at $270 \mathrm{~nm}$. Decolorization of RB5 was determined in $100 \mathrm{mM}$ sodium tartrate buffer $\mathrm{pH} 3$ with $10 \mu \mathrm{M}$ RB5. The reaction was monitored through a decrease in absorbance at $598 \mathrm{~nm}\left(\mathrm{e}_{598} 24000 \mathrm{M}^{-1} \mathrm{~cm}^{-1}\right)$. Reactions for the determination of peroxidases were initiated with $0.1 \mathrm{mM} \mathrm{H}_{2} \mathrm{O}_{2}$.

\section{RNA isolation and sequencing}


Fungal biomass was filtered from the culture supernatant on day 7 during the late log phase and ground to fine powder using liquid nitrogen. Total RNA was isolated using a Genetix RNA sure Plant minikit according to the manufacturer's protocol. The concentration of RNA was measured on a NanoDrop spectrophotometer, and the quality was assessed by denaturing agarose gel electrophoresis. A total of 1 mg of total RNA was used for analysis, wherein mRNA was enriched from total RNA using poly T attached magnetic beads. Sequencing libraries were prepared using a TruSeq stranded library preparation kit, and quality was assessed using an Agilent 4200 Tape station. The library was then subjected to paired end sequencing on the Illumina NextSeq 500 platform.

\section{Reads mapping and annotation}

Raw reads were processed in Trimmomatic v0.35 to remove adapter sequences and ambiguous and lowquality sequences. The quality reads were then assembled in CLC assembly cells. Annotation was performed using BLAST2GO 5.2 software for identification of Gene Ontology (GO) terms [16]. Exhaustive functional annotations of the transcript sequences were performed through Function annotator [17]. Function Annotator assisted in annotation of enzymes, best hits to NCBI nr database, GO terms, conserved domain, transmembrane protein, lipoprotein peptide, signal peptide and subcellular localization. KEGG orthology designation was obtained based on homology searches in KAAS [18].

\section{CAZyme annotation}

The catalytic and other functional domains of enzymes involved in the metabolism and transport of carbohydrates were elucidated based on signature domains of each CAZy family through the dbCAN2 meta server [19]. Short sequence reads were submitted to the dbCAN2 meta server for automated CAZyme annotation using the tools HMMER, DIAMOND and Hotpep. The CAZyme domain HMM database is used for the identification of CAZyme domain boundaries, whereas DIAMOND is used for fast homology-based searches of the CAZy database. Hotpep identifies conserved motifs in the peptide pattern recognition (PPR) library. In addition, conserved unique peptide patterns in the CAZymes placed them in different functionally related protein groups (CUPPs). A Finer level of classification based on the similarity of protein sequences and peptide signatures of the CUPP group was used to classify protein families of the transcript sequences [20].

mycoCLAPAnalysis

Further functional analysis of lignocellulose active proteins was acquired through mycoCLAP [21]. The mycoCLAP database contains comprehensive information on fungal and bacterial genes encoding lignocellulose-acting proteins that were characterized through biochemical studies. Transcript sequences generated were subjected to homology search against the mycoCLAP sequences through BLAST for significant insight into the lignocellulose acting proteins present in the transcriptome.

\section{Gene prediction}


Gene identification was accomplished through the AUGUSTUS web server, a gene prediction software based on the generalized hidden Markov model [22]. The short read nucleotide sequences were fed as input to the AUGUSTUS web server for gene predictions based on Phanerochaete chrysosporium, another white-rot genome. Parameters were set to detect genes from both strands and through alternate splicing. Another $a b$ initio gene prediction software, FGENESH, based on the hidden Markov model was also used for gene identification [23]. Sequences were uploaded to FGENESH for gene prediction using organismspecific gene finding parameters of Trametes cinnabarina, a white rot that displayed significant nucleotide sequence homology in the Function Annotator.

\section{Results}

\section{Enzyme activity measurements}

L. squarrosulus was grown in simple synthetic medium with Reactive Black 5 (RB5), an azo dye that induces the production of ligninolytic enzymes. Our previous work on ligninolytic enzymes demonstrated that these enzymes were strongly stimulated in the presence of aromatic compounds and lignocellulose substrates. In particular, the recalcitrant dye RB5 stimulated higher titers of ligninolytic peroxidases.

Lignin-degrading enzymes of this fungus, particularly versatile peroxidase, manganese peroxidase and laccase, were strongly induced in the presence of azo dye (Figure 1). [L1] Manganese oxidizing peroxidase activity increased to a maximum of $10 \mathrm{U} / \mathrm{ml}$ in induced medium compared to the uninduced medium in addition to laccase activity. The biomass-degrading enzyme activities of cellulase, xylanase, polygalacturonase, mannanase, a-glucosidase, $\beta$-glucosidase and xylan esterase were studied to obtain a deeper understanding of the regulation of these enzymes compared to ligninolytic enzymes. Only trivial aglucosidase activity was observed in induced and uninduced media. The interference of the mannanase substrate locust bean gum with glucose in the culture supernatant impeded the detection of this enzyme.

An increase in cellulase activity was observed on day 7 , with higher activity in uninduced medium than in induced medium. The same trend was observed with xylanase, acetyl esterase and polygalacturonase, whereas $\beta$-glucosidase activity was higher in induced medium. Although the maximum activity and duration varied for each enzyme, the performance of the uninduced medium was optimal for the production of biomass-degrading enzymes other than ligninolytic enzymes. Ligninolytic enzyme activity was higher in the induced medium, which was attributed to the complex aromatic nature of the azo dye. This evidently signified that the specific activity of ligninolytic enzymes was higher in the induced medium.

\section{RNA extraction and sequencing}

cDNA sequencing libraries were prepared from total RNA of late log phase cultures of $L$.

squarrosulus grown in RB5-induced potato dextrose broth. Ten million reads of data were generated from an initial RNA concentration of $125 \mathrm{ng} / \mathrm{ml}$ with a mean fragment size of $447 \mathrm{bp}$. A total of $6,679,162$ high-quality paired-end reads were obtained after removal of adaptor sequences and trimming of low- 
quality bases. The raw reads were aligned de novo through CLC assembly cells, and 25,244 contigs were obtained (Table 1).[L2]

Table 1: Summary of L. squarrosulus transcriptome assembly

\begin{tabular}{ll} 
Number of contigs & 25,244 \\
\hline Total size of contigs (bp) & $2,31,81,074$ \\
\hline Average Length (bp) & 918 \\
\hline Length SD (bp) & 856 \\
\hline GC content (\%) & 57.93 \\
\hline N50 contig length (bp) & 1,340 \\
\hline N50 contig count & 5,091
\end{tabular}

\section{Functional annotation}

Annotation of the sequences based on similarity was performed using BLAST2GO. BLAST2GO was used to determine the putative functions of the transcripts and categorize them by biological process, cellular component and molecular function. To further explore the function and significance of the transcripts, the sequences were analyzed through Function annotator. Functional annotator presented efficient interpretation of the reads on GO terms, enzyme groups, domain identification, subcellular localization, protein secretion, transmembrane proteins and on the taxonomic relationship at different levels. Sequence similarity with the NCBI nonredundant database yielded equivalent sequences with the lowest e-values.

The taxonomic information was furnished based on the proportion of similar sequences in $L$. squarrosulus close to Dichomitus squalens at the species level. The subsequent best hits were Trametes versicolor and Trametes cinnabarina, as depicted in Figure 2. Polyporaceae are a major group of white-rot fungi with L. squarrosulus, Dichomitus squalens and Trametes versicolor belonging to the core polyporoid clade, one of the major clades with rich catabolic ability under Polyporales. Analysis based on ITS, RNA polymerase II and nrLSU sequences supports the similarity of Lentinus to Dichomitus and Trametes at the genus level [24].

Gene Ontology terms for the transcripts were annotated through BLAST2GO and functional annotators. 3,365 GO terms were assigned to 10,494 transcripts. The most abundant $\mathrm{GO}$ term predicted by Function annotator was G0:0055114, specifying the oxidation-reduction process (biological process) with gene products marking to manganese peroxidase 3 precursor of Phlebia radiata (PEM3_PHLRA), laccase 1A of Trametes pubescens (AF414808.1, AF491761, AF414807.1), ligninase H2 of Phanerochaete chrysosporium(LIG4_PHACH), mannitol dehydrogenase (MTLD_BACP2), NADPH dependent D-xylose reductase (XYL1_CANBO), arabinitol dehydrogenase (ARD1_UROFA), arabinan endo-1,5-alpha-L- 
arabinosidase A (ABNA_EMENI), pyranose dehydrogenase (PDH3_LEUMG), a-fucosidase A (AFCA_ASPNC). This substantiates the potential of this fungus in biomass degradation through the production of diverse hydrolytic enzymes. Subsequently, the enriched GO terms were G0:0005524 (molecular function: ATP binding), G0:0008152 (cellular function: metabolic process) and G0:0016021 (cellular component: integral membrane components). Deeper classification of each of the GO terms predicted for the contigs was also visualized through a function annotator that presented fifteen levels of classification for each GO category.

Best matching hits of the putative proteins encoded by the transcripts against the NCBI nonredundant protein database were available for 16,779 transcripts that expressed similarity to chiefly Dichomitus and Trametes protein sequences.3,217 probable enzyme products likely to be produced by 12,379 transcripts were determined through PRIAM based on the ENZYME database. Although the most abundant hits were proteins involved in genome integrity and regulation, such as RNA-dependent RNA polymerase, RNA helicase, and protein kinases, there were significant representations of biomass-degrading enzymes, such as endo-1,3(4)-beta-glucanase, glucose oxidase, choline oxidase and a range of lignocellulose active enzymes, as depicted in Figure 3. This demonstrates that the expression of these enzymes by the fungus is not dependent on the presence of lignocellulose substrate in the culture medium.

Putative domain hits illustrated by functional annotators were based on the PFAM database. A total of 4952 unique conserved domains were identified against 11,585 transcripts. The most abundant domain hit was Major Facilitator Superfamily of secondary transporters (pfam07690), followed by Tymo_45kd_70kd (pfam03251), a kind of transposable element detected in Basidiomycetes. Similar transposable elements were also reported in Pleurotus ostreatus[25].

KEGG orthology designations were obtained for 3,327 transcripts. Transcripts encoding 20 putative cytochrome $\mathrm{P} 450$ polypeptides were present in the $L$. squarrosulus transcriptome. The probable pathway depiction for cytochrome P450 was metabolism of xenobiotics. In addition, mannosidase, $\mathrm{a}$ - and $\beta$ glucosidases, galactosidase, arabinofuranosidase, endoglucanase, pectin esterase, and polygalacturonase were identified, establishing the biodegradative potential of this fungus.

In addition to the representation of sequences involved in fungal internal metabolism, translation and transcription, there was considerable expression of a two-component signal transduction system coupled with the transcription factor SKN7. The SKN7 transcription factor is an important member of the twocomponent phosphorylation system that transfers signals to activate the promoters of genes in response to external stimuli and induces responses to oxidative stress, such as $\mathrm{H}_{2} \mathrm{O}_{2}$ [26]. In addition, multiple RTA1 domain-containing protein sequences were observed, again related to the stress response.

There was significant representation of contigs specifying laccase, as revealed through similarity searches to the nr database and by GO annotation. Laccase, a multicopper oxidase, catalyzes the oxidation of phenolic compounds using a molecular oxygen electron acceptor, as pointed out in the molecular function of the enzyme by GO as hydroquinone: oxygen oxidoreductase activity, with 
hydroquinone being a diphenol compound. Laccases are efficient in degrading the phenolic components of lignin and play a major role in lignin catabolic processes. Six transcripts of laccase were expressed in L. squarrosulus with $100 \%$ sequencecongruence to laccases of Trametes cinnabarina, Polyporus, and Lentinus tigrinus. Ten transcript sequences were found to encode proteins homologous to versatile peroxidase with significant protein similarity to versatile peroxidase protein isoforms of Pleurotus eryngii and of Trametes versicolor. Protein sequences of putative versatile peroxidases were subjected to multiple alignment through CLUSTALW with experimentally determined protein sequences of ligninolytic peroxidases in the Protein Data Bank (PDB). The phylogenetic tree rooted through the UPGMA method of the alignment is presented in Figure 4.

Two isoforms of manganese peroxidase were identified based on conserved domains and sequence similarity. However, no lignin peroxidase transcripts were observed in this species, as confirmed through biochemical analysis.

Peroxidases are more prominent in the lignin catabolic process due to their relatively high redox potential and hence require complete mineralization of lignin. The efficient function of ligninolytic machinery is indispensable without hydrogen peroxide, an electron acceptor for peroxidases. White-rot fungi produce $\mathrm{H}_{2} \mathrm{O}_{2}$ needed for lignin oxidation through diverse enzymes such as glyoxal oxidase, aryl-alcohol oxidase, aryl alcohol dehydrogenase and GMC oxidoreductases [27]. Glyoxal oxidase of this fungus exhibited $66 \%$ similarity in protein sequence to that of Phanerochaete chrysosporium. Multiple transcript copies of these enzymes were expressed by the fungus. A considerable depiction of $\mathrm{H}_{2} \mathrm{O}_{2}$-producing oxidases was made by the glucose-methanol-choline (GMC) superfamily encoding transcripts that supply the peroxide requisite for ligninolytic peroxidases.

Enhancement of the oxidoreduction process in the culture of this fungus was further validated by the ubiquitous presence of cytochrome P450 monooxygenases and oxidoreductases in the transcriptome $[28,29]$. Cytochrome $P 450$ enzymes are involved in the catalytic reaction of aromatic metabolism through diverse biochemical reactions. The enzymatic reaction of cleavage of $\beta-0-4$ linkages of lignin is enhanced by co-oxidants such as thiols, $\mathrm{NAD}^{+}$, glutathione, etc. Glutathione reductase enables regeneration of reduced glutathione and is expressed in cells exposed to oxidative stress [30]. Evidently, glutathione reductase was expressed in $L$. squarrosulus with considerable protein similarity to glutathione reductase of Dichomitus squalens. In addition, sequences of flavin-containing monooxygenases (FMOs) and dioxygenases were revealed in the transcriptome analysis. FMOs are proteins involved in degradation in a multitude of aromatics and have been reported in a number of fungal species, while dioxygenases are reportedly involved in ring cleavage of aromatics oxidation [31]. The reactive peroxides produced create a highly oxidative environment for enzymatic action. Fungi secrete svf1 protein in response to this oxidative stress for their survival, as evident through the sequences of oxidative stress survival svf1-like protein expressed by L. squarrosulus [32].

Plant polysaccharides are composed of cellulose, hemicellulose, pectin and lignin, which contribute to the bulk of the biomass. In addition to the expression of lignin-degrading enzymes in response to induction 
by aromatic compounds, polysaccharide-degrading enzymes also existed in the transcriptome, with regulation different from that of the control, mediuming a synergy in regulation of the former and the latter. Endoglucanase, cellobiohydrolase and $\beta$-glucosidase enzymes are important components of the cellulolytic machinery [33], and L. squarrosulus demonstrated the presence of mRNAs of these genes. Pectin lyase-like proteins belong to glycosyl hydrolase family 28 , which acts by inverting the mechanism of a1,4 glycosydic linkage of polygalacturonates [34]. Sequences with pectin lyase-like protein activity belonging to pectin esterase and polygalacturonase in the transcriptome of this species state its role in the degradation of pectin. In addition to pectin lyases, transcripts of polysaccharide lyase classes of proteins were also expressed. In addition, there was a strong representation of substrate transporters, glycoside hydrolases, glycoside transferases, carbohydrate esterases and acetyl xylan esterases encompassing the major plant polysaccharide-degrading enzymes.

\section{CAZyme annotation}

The fungus undertaken in the current study was an extensive producer of a multitude of plant polysaccharide-degrading enzymes spanning across the families of carbohydrate-active enzymes. Fungal systems are reportedly affected by polysaccharide-degrading enzymes, and the enzymes acting on these polysaccharides in general are designated 156 families of glycoside hydrolases, 106 families of glycosyl transferases, 16 families of carbohydrate esterases and 29 families of polysaccharide lyases [35]. The transcriptome was enriched with transcripts of esterases of family carbohydrate esterases 10. Carbohydrate esterases deacetylate the conjugates of glucans and are binding components of polysaccharide-degrading machinery. Glycoside hydrolases of family 16 showed significant depiction in the transcriptome of L. squarrosulus. Additionally, the transcript sequences of six and seven hairpin glycosidases catalyzing 0-glycosyl bonds were observed. This emphasizes the importance of this fungus in the catabolism of carbohydrates, primarily cellulose, hemicellulose and pectic polysaccharides. In this bracket, endoglucanases, $\beta 1,3-1$, and 4 glucanases, xyloglucanases, and xyloglucan:xyloglucosyl transferases are worth remarkable mention.

Chitinases of glycoside hydrolase family 18 were subsequently predominant and were supposed to be involved in cell wall remodeling and maintenance of the fungus. More than ten transcripts with $\mathrm{GH} 3$ and GH79 modules were identified in the transcriptome of $L$. squarrosulus. Similarly, ligninolytic enzymes that act in synchronization with glycoside hydrolases were also preponderant in the transcriptome, as revealed by CAZyme annotation belonging to the AA2 family. The other affluent CAZymes reported were GMC oxidoreductase (AA3), lytic polysaccharide monooxygenases cleaving cellulose chains (AA9) and lytic polysaccharide monooxygenases cleaving xylans (AA14). The overall distribution of CAZymes in the transcriptome based on dbCAN is illustrated in Figure 5-7.

CUPP assigned 508 transcripts to 6 families of polysaccharide lyases, 51 families of glycoside hydrolases, 23 families of glycoside transferases, 7 families of carbohydrate esterases and 10 families of auxiliary activities family. Of the enzymes characterized through CUPP based on the peptide signatures, chitinase (3.2.1.14) and chitin synthase (2.4.1.16) were predominant, followed by laccase (1.10.3.2). Ten 
transcript sequences were assigned to the laccase family, and seven transcripts encoded peptide signatures typical of versatile peroxidase (1.11.1.16). The top hits also included glyoxal oxidase (1.2.3.15) and glucan endo-1,3-beta-D-glucosidase (3.2.1.39). Prediction of CAZy families on peptide signatures revealed preponderance of glycosidehydrolases followed by auxiliary activities 3 family. Among the glycoside hydrolases, GH16 and GH18 were enriched in the transcript sequences of $L$. squarrosulus. $\mathrm{GH} 16$ comprises members that are active on $\beta-1,4$ and 1,3 glycosidic bonds, and $\mathrm{GH} 18$ members chitinase and endo- $\beta-\mathrm{N}$-acetylglucosaminidase aid in the maintenance of the fungal cell wall, whereas $\mathrm{GH} 5$ activities include cellulases, endomannanases and xyloglucanases.

The auxiliary activities 2 family encoding lignin modifying peroxidases manganese peroxidase and versatile peroxidase were also abundant subsequent to glycoside hydrolases and auxiliary activities family 3.

Table 2:Nucleotide hits against mycoCLAP database. 


\begin{tabular}{|c|c|c|}
\hline $\begin{array}{l}\text { Transcript } \\
\text { ID }\end{array}$ & Gene hit & Organism \\
\hline Lsqua2 & 4-beta-D-glucan cellobiohydrolase & $\begin{array}{l}\text { Aspergillus aculeatus } \\
\text { Aspergillus niger }\end{array}$ \\
\hline Lsqua3 & 4-beta-D-glucan cellobiohydrolase & $\begin{array}{l}\text { Aspergillus aculeatus } \\
\text { Aspergillus niger }\end{array}$ \\
\hline Lsqua4 & 4-beta-D-glucan cellobiohydrolase & Aspergillus aculeatus \\
\hline Lsqua49 & 4-hydroxy-3-methoxycinnamoyl-sugar hydrolase & Emericella nidulans \\
\hline Lsqua69 & 4-hydroxy-3-methoxycinnamoyl-sugar hydrolase & Emericella nidulans \\
\hline Lsqua325 & 4-beta-D-glucan 4-glucanohydrolase & Polyporus arcularius \\
\hline Lsqua581 & 4-hydroxy-3-methoxycinnamoyl-sugar hydrolase & Emericella nidulans \\
\hline Lsqua1786 & 4-hydroxy-3-methoxycinnamoyl-sugar hydrolase & Emericella nidulans \\
\hline Lsqua2739 & xylan 2-alpha-D-(4-0-methyl)glucuronohydrolase & Schizophyllum commune \\
\hline Lsqua4334 & 3-beta-D-glucan glucanohydrolase & $\begin{array}{l}\text { Phanerochaete } \\
\text { chrysosporium }\end{array}$ \\
\hline Lsqua5831 & 4-hydroxy-3-methoxycinnamoyl-sugar hydrolase & Emericella nidulans \\
\hline Lsqua5892 & 4-beta-D-glucan cellobiohydrolase & $\begin{array}{l}\text { Fusicoccum sp } \\
\text { Aspergillus aculeatus } \\
\text { Humicola grisea var. } \\
\text { thermoidea }\end{array}$ \\
\hline Lsqua6691 & $\begin{array}{l}\text { 1,2-bis(3,4-dimethoxyphenyl)propane-1,3- } \\
\text { diol:hydrogen-peroxide } \\
\text { oxidoreductase }\end{array}$ & Trametes versicolor \\
\hline Lsqua6888 & 4-beta-D-glucan cellobiohydrolase & $\begin{array}{l}\text { Phanerochaete } \\
\text { chrysosporium } \\
\text { Fusicoccum sp. } \\
\text { Aspergillus niger }\end{array}$ \\
\hline Lsqua6889 & 4-beta-D-glucan cellobiohydrolase & $\begin{array}{l}\text { Chaetomium thermophilum } \\
\text { Humicola grisea var. } \\
\text { thermoidea } \\
\text { Phanerochaete } \\
\text { chrysosporium } \\
\text { Fusicoccum sp. } \\
\text { Irpex lacteus } \\
\text { Aspergillus niger }\end{array}$ \\
\hline Lsqua7174 & alpha-L-arabinofuranoside arabinofuranohydrolase & Meripilus giganteus \\
\hline Lsqua10724 & beta-D-mannoside mannohydrolase & $\begin{array}{l}\text { Myceliophthora } \\
\text { thermophila }\end{array}$ \\
\hline Lsqua11832 & 4-beta-D-glucan 4-glucanohydrolase & Gloeophyllum trabeum \\
\hline
\end{tabular}




\begin{tabular}{|c|c|c|}
\hline Lsqua13413 & 6-beta-D-glucan glucanohydrolase & Trichoderma harzianum \\
\hline Lsqua13746 & PM09D_PHACH | AB670125 & $\begin{array}{l}\text { Phanerochaete } \\
\text { chrysosporium }\end{array}$ \\
\hline Lsqua13896 & 4-beta-D-glucan cellobiohydrolase & $\begin{array}{l}\text { Melanocarpus albomyces } \\
\text { Chaetomium } \\
\text { thermophilum } \\
\text { Humicola grisea var. } \\
\text { thermoidea } \\
\text { Fusicoccum sp. }\end{array}$ \\
\hline Lsqua15180 & 4-beta-D-glucan 4-glucanohydrolase & $\begin{array}{l}\text { Myceliophthora } \\
\text { thermophila }\end{array}$ \\
\hline Lsqua16188 & beta-D-glucoside glucohydrolase & $\begin{array}{l}\text { Phanerochaete } \\
\text { chrysosporium }\end{array}$ \\
\hline Lsqua19240 & 4-beta-D-glucan cellobiohydrolase & $\begin{array}{l}\text { Phanerochaete } \\
\text { chrysosporium }\end{array}$ \\
\hline Lsqua20450 & 4-beta-D-glucan glucanohydrolase & $\begin{array}{l}\text { Macrophomina phaseolina } \\
\text { Trichoderma sp }\end{array}$ \\
\hline Lsqua21909 & 6-beta-D-glucan glucanohydrolase & Trichoderma harzianum \\
\hline Lsqua25064 & 4-beta-D-xylan xylanohydrolase & $\begin{array}{l}\text { Phanerochaete } \\
\text { chrysosporium }\end{array}$ \\
\hline
\end{tabular}

\section{MyCOCLAP ANALYSIS}

Homology search results against the mycoCLAP nucleic acid sequence database of approximately 833 sequences functioning in lignocellulose degradation are depicted in Table 2. The ranking of search results was based on the closest biochemically characterized homolog.

Gene prediction

The predicted proteins of six transcripts corresponded to laccases, multicopper oxidases. The protein sequences predicted by AUGUSTUS and FGENESH were similar except for slight length variations for a few transcripts. Laccase expression was visualized in medium devoid of external supplementation of copper in contrast to cultures requiring $\mathrm{Cu}^{2+}$ addition for laccase induction [36, 37]. Although two of the sequences were only partial, three sequences encoded proteins with lengths $>399$ aa. The predicted proteins exhibited more than $90 \%$ similarity to laccases of Lentinus tigrinus and Polyporus brumalis. The sequences exhibited conserved L1-L4 signatures typical of laccases[38] involved in copper ion binding. Ten transcripts were identified to encode the product of versatile peroxidase as assessed through amino acid sequence alignment. The sequences exhibited significant homology with manganese-dependent and repressed peroxidase isoforms of Lentinus tigrinus and Trametes versicolor. Some sequences presented partial heme and metal ion binding domains. A complete versatile peroxidase coding sequence was also predicted with $92 \%$ protein identity to the manganese peroxidase 1 isoform of Lentinus tigrinus. The predicted proteins did include fatty acid dehydrogenases involved in peroxidation of lipids, which 
generates lipid radicals as ligninolytic oxidants for nonphenolic lignin degradation by manganese peroxidases. Protein sequence comparison of predicted ligninolytic enzymes is illustrated in Table 3.

Table 3: Putative ligninolytic enzymes of $L$. squarrosulus

\begin{tabular}{|c|c|c|c|c|c|}
\hline $\begin{array}{l}\text { Transcript } \\
\text { ID }\end{array}$ & $\begin{array}{l}\text { Putative } \\
\text { Function }\end{array}$ & BLAST best hit & $\begin{array}{l}\text { Sequence } \\
\text { length }\end{array}$ & $\begin{array}{l}\text { e- } \\
\text { value }\end{array}$ & $\begin{array}{l}\text { Amino } \\
\text { acid } \\
\text { identity }\end{array}$ \\
\hline \multirow[t]{2}{*}{ Lsqua4933 } & \multirow{2}{*}{$\begin{array}{l}\text { Versatile } \\
\text { Peroxidase }\end{array}$} & manganese peroxidase 1 & \multirow[t]{2}{*}{ 369aa } & \multirow[t]{2}{*}{0} & \multirow[t]{2}{*}{$92 \%$} \\
\hline & & [Lentinus tigrinus] & & & \\
\hline Lsqua 6622 & $\begin{array}{l}\text { Versatile } \\
\text { Peroxidase }\end{array}$ & $\begin{array}{l}\text { manganese-repressed peroxidase } \\
\text { [Trametes versicolor] }\end{array}$ & $280 a a$ & $4 e^{-139}$ & $72 \%$ \\
\hline Lsqua18051 & $\begin{array}{l}\text { Versatile } \\
\text { Peroxidase }\end{array}$ & $\begin{array}{l}\text { manganese peroxidase isozyme } \\
\text { precursor [Polyporus brumalis] }\end{array}$ & 179aa & $8 e^{-117}$ & $94 \%$ \\
\hline Lsqua10154 & $\begin{array}{l}\text { Versatile } \\
\text { Peroxidase }\end{array}$ & $\begin{array}{l}\text { Mn peroxidase MNP6 [Lentinus } \\
\text { tigrinus] }\end{array}$ & $168 a a$ & $1 e^{-109}$ & $96 \%$ \\
\hline Lsqua13135 & $\begin{array}{l}\text { Versatile } \\
\text { Peroxidase }\end{array}$ & $\begin{array}{l}\text { manganese peroxidase isozyme } \\
\text { precursor [Lentinus tigrinus] }\end{array}$ & 72aa & $7 e^{-35}$ & $86 \%$ \\
\hline Lsqua15894 & $\begin{array}{l}\text { Versatile } \\
\text { Peroxidase }\end{array}$ & $\begin{array}{l}\text { manganese peroxidase isozyme } \\
\text { precursor [Lentinus tigrinus] }\end{array}$ & $65 a a$ & $1 e^{-31}$ & $92 \%$ \\
\hline Lsqua15340 & $\begin{array}{l}\text { Versatile } \\
\text { Peroxidase }\end{array}$ & $\begin{array}{l}\text { manganese peroxidase isozyme } \\
\text { precursor [Lentinus tigrinus] }\end{array}$ & 135aа & $2 e^{-84}$ & $93 \%$ \\
\hline Lsqua10666 & $\begin{array}{l}\text { Versatile } \\
\text { Peroxidase }\end{array}$ & $\begin{array}{l}\text { Mn peroxidase MNP6 [Lentinus } \\
\text { tigrinus] }\end{array}$ & $76 a a$ & $3 e^{-38}$ & $87 \%$ \\
\hline Lsqua14505 & $\begin{array}{l}\text { Versatile } \\
\text { Peroxidase }\end{array}$ & $\begin{array}{l}\text { Mn peroxidase MNP6 [Lentinus } \\
\text { tigrinus] }\end{array}$ & $76 a a$ & $3 e^{-38}$ & $87 \%$ \\
\hline Lsqua12314 & $\begin{array}{l}\text { Versatile } \\
\text { Peroxidase }\end{array}$ & heme peroxidase [Lentinus tigrinus] & 406aa & 0 & $80 \%$ \\
\hline Lsqua20933 & Laccase & laccase [Lentinus tigrinus] & $68 a a$ & $9 e^{-24}$ & $72 \%$ \\
\hline Lsqua6164 & Laccase & laccase 1 [Polyporus brumalis] & $516 a a$ & 0 & $88 \%$ \\
\hline Lsqua18153 & Laccase & laccase [Polyporus brumalis] & 474aa & 0 & $92 \%$ \\
\hline Lsqua18367 & Laccase & laccase LCC3-3 [Polyporus ciliatus] & 399aa & 0 & $93 \%$ \\
\hline Lsqua21132 & Laccase & $\begin{array}{l}\text { Cu-oxidase-domain-containing } \\
\text { protein [Lentinus tigrinus] }\end{array}$ & 133aа & $3 e^{-84}$ & $96 \%$ \\
\hline Lsqua21539 & Laccase & laccase [Lentinus tigrinus] & 244aa & $1 \mathrm{e}^{-149}$ & $91 \%$ \\
\hline
\end{tabular}

\section{Discussion}


Basidiomycetes, particularly white-rot fungi, have been investigated exhaustively for their selective delignification ability and for the efficiency of lignin degradation. These fungi degrade plant biomass through a repertoire of biomass-degrading enzymes. In these lines, there has been tremendous effort to deepen the understanding of the biomass metabolic process, especially the lignin catabolic process, as degradation of lignin will facilitate competent utilization of the underlying polysaccharides. Ligninolytic enzymes are reported to be secreted in response to stress, such as nutrient limitation and the presence of recalcitrant aromatic compounds, and are triggered by the presence of metal ions, such as $\mathrm{Cu}^{2+}$ and $\mathrm{Mn}^{2+}$, in the case of laccase and manganese peroxidase, respectively $[4,36,38,39]$. White-rot fungal species vary widely in their ability to secrete these biomass-degrading enzymes, and enzyme production itself is largely influenced by growth conditions and the presence of substrates [40]. With the accumulation of genomic data on white-rot fungal species, the characterization of biomass-degrading enzymes for functional exploitation has increased. Transcriptomic studies have also revealed the expression of an array of catabolic enzymes differentially based on the lignocellulosic substrate $[4,5,6$, 9 , 41]. Accordingly, in our study, we studied the transcriptome of $L$. squarrosulus, a white rot belonging to the Polyporaceae family grown in simple culture medium with azo dye RB5 added for ligninolytic enzyme induction. Our study was focused on studying the expression of degradative enzymes in simple medium and was not intended for differential expression analysis. However, the transcriptomic profile of this fungus correlated well with the transcriptomic data of other white-rot fungi available $[6,8,42]$. There was significant expression of CAZymes, especially ligninolytic enzymes, in the induced medium, in support of the fact that ligninolytic enzymes are mainly expressed in nutrient-limited conditions rather than in the presence of lignocellulosic substrates. Multiomics studies on Phanerochaete chrysosporium lignocellulolytic networks also substantiated that nutrient limitation was a major driver of ligninolytic and cellulolytic gene expression rather than the presence of lignocellulosic substrates [4]. Cellulase, xylanase, polygalacturonase, $\beta$-glucosidase, laccase and versatile peroxidase are shown to be produced in considerable amounts despite the lack of lignocellulosic substrate. A noteworthy observation is an increase in the amount of ligninolytic enzymes secreted in comparison to the control medium. Putative cellulases (EC 3.2.1.4) and xylanases (EC 3.2.1.8) were identified in the transcriptome of our fungus despite the presence of glucose in the medium, which is presumed to cause catabolite repression. However, the glucose concentration in the medium during the period of RNA isolation was comparatively low, which might have plausibly caused the expression of cellulose-degrading enzymes. In addition, transcripts encoding putative hemicellulose-degrading enzymes of arabinanase, xylosidase, and mannanase were also expressed in the transcriptome of $L$. squarrosulus. These results are in contrast to the transcriptomic analysis of Pycnoporus sanguineus also grown in the absence of lignocellulosic substrate wherein cellulases were not present [42]. However, in our present study, cellulases and hemicellulases were perceived to be expressed even in the absence of lignocellulosic substrates. In addition, lytic polysaccharide monooxygenases (LPMO), pectinases and a range of other polysaccharidedegrading enzymes were detected, elucidating the superior biodegradative ability of the fungus. Similar oxidative enzymes acting on polysaccharides were expressed in Ceriporiopsissubvermispora and Phanerochaete chrysosporium cultures containing lignocellulosic substrates $[43,44]$. Ligninolysis is substantially connected to free radical and peroxide production. The L. squarrosulus transcriptome 
revealed diverse peroxide-generating enzymes, such as cellobiose dehydrogenases, aryl alcohol oxidases and other glucose-methanol-choline oxidoreductases. In summary, the fungus undertaken in our study, $L$. squarrosulus, is evidently competent to efficiently degrade lignocelluloses through its extensive machinery of hydrolytic and oxidative enzymes targeting multiple components of the substrate. Additionally, these enzymes working on lignocellulose bioconversion also react on diverse aromatic compounds, such as dyes, pesticides, endocrine disruptors and other environmental contaminants, which convey their importance. Although multiple white-rot Basidiomycetes were studied for lignin degradation, each species is unique in its ability to oxidize aromatic macromolecules.

\section{Conclusion}

Although there are multiple studies on the biochemical characterization of lignocellulolytic enzymes of $L$. squarrosulus, research on the expression pattern of lignocellulose-degrading enzymes has not been attempted. This study on the transcriptome analysis of $L$. squarrosulus revealed significant facts on this front and will definitely enhance the knowledge about the biodegradative ability of this fungus, potentially paving the way for efficient biotechnological applications utilizing its potency in biomass degradation and its future functional exploitation in biomass conversion applications.

\section{Abbreviations}

Reactive black 5 -RB5

Dinitro salicylic acid -DNS

2,2-azino-bis(3-ethylbenzothiazoline-6-sulfonate-ABTS

Gene Ontology -GO

Peptide Pattern Recognition -PPR

Protein Data Bank -PDB

Glucose-Methanol-Choline -GMC

Flavin containing monooxygenases -FMO

\section{Declarations}

All manuscripts must contain the following sections under the heading 'Declarations':

\section{Ethics approval and consent to participate}

Not applicable 


\section{Consent for publication}

Not applicable

\section{Availability of data and material}

The raw sequencing data referred to in this project were submitted to the NCBI Sequence Read Archive under the accession number PRJNA640439 (Release date: 2021-07-01). All data generated or analyzed during this study are included in this published article [and its supplementary information files].

\section{Competing interests}

The authors declare that they have no competing interests.

\section{Funding}

This work was carried out under the financial assistance provided by the Department of Science and Technology (DST), Ministry of Science and Technology, Govt. of India, under the Women Scientist -A scheme provided to the first author.

\section{- Authors' contributions}

AR and MS planned the study and were a major contributor in writing the manuscript. AR executed the research work. APK and AD designed and assisted in transcriptome studies. All authors read and approved the final manuscript.

- Acknowledgments

Financial assistance was provided by the Department of Science and Technology (DST), Ministry of Science and Technology, Govt. of India under the WOSA scheme (SR/WOS-A/LS-32/2016) is gratefully acknowledged by the first author. The authors thank the Director, ICAR - National Institute of Animal Nutrition and Physiology, Bangalore (Karnataka) India, for providing the necessary facilities to carry out the research work.

\section{References}

1. Valverde ME, Hernández-Pérez T, and Paredes-López O (2015) Edible Mushrooms: Improving Human Health and Promoting Quality Life. Int J of Microbiol:14.

2. Kent KT (1987) Enzymatic 'combustion', the microbial degradation of Lignin. Ann. Rev. Microbiol 41: 465-505.

3. Sridhar M and Ravichandran A (2017) Insights into the mechanism of lignocellulose degradation by versatile peroxidases. Curr sci 113:35-42. 
4. Wymelenberg AV, Gaskell J, Mozuch M, Kersten P, Sabat G, Martinez D, Cullen D (2009) Transcriptome and secretome analyses of Phanerochaete chrysosporium reveal complex patterns of gene expression. Appl Environ Microbiol 5(12):4058-68.

5. Chen Y, Cao Q, Tao X, Shao H, Zhang K,Zhang YZ and Tan X (2016) Analysis of de novo sequencing and transcriptome assembly and lignocellulolytic enzymes gene expression of Coriolopsis gallica HTC. Biosci Biotechnol Biochem 81(3):460-468.

6. Zhang L, Wang Z, Wang Y, Huang B (2017) Transcriptomic profile of lignocellulose degradation from Trametes versicolor on poplar wood. Bioresources 12(2):2507-2527.

7. Makela“" MR, Sietio“ O-M, de Vries RP, Timonen S, Hilde'́n K (2014) Oxalate-Metabolizing Genes of the White-Rot Fungus Dichomitus squalens Are Differentially Induced on Wood and at High Proton Concentration. PLoS ONE 9(2): e87959.

8. Korripally P, Hunt CG, Houtman CJ, Jones DC, Kitin PJ, Cullen D and Hammel KE (2015) Regulation of gene expression during the onset of ligninolytic oxidation by Phanerochaete chrysosporium on spruce wood. Appl Environ Microbiol 81:7802-7812.

9. Qin X, Su X, Luo H, Ma R, Yao B and Ma F (2018) Deciphering lignocellulose deconstruction by the white rot fungus Irpex lacteus based on genomic and transcriptomic analyses. Biotechnol Biofuels 11:58.

10. Shewale JG and Sadana JC (1978) Cellulase and $\beta$-glucosidase production by a basidiomycete species. Can J Microbiol 24(10):1204-16.

11. Li Q, Coffman AM and Ju LK (2015) Development of reproducible assays for polygalacturonase and pectinase. Enzyme Microb Technol 72:42-8.

12. Kataoka $\mathrm{N}$ and Tokiwa $\mathrm{Y}$ (1998) Isolation and characterization of an active mannanase producing anaerobic bacterium, Clostridium tertium KT-5A, from lotus soil. J Appl Microbiol 84(3):357-67.

13. Miller GL (1959) Use of Dinitrosalicylic Acid Reagent for Determination of Reducing Sugar. Anal Chem 31(3): 426-428.

14. Biely P, Puls J and Schneidera H (1985) Acetyl xylan esterases in fungal cellulolytic systems. FEBS Lett 186(1):80-84.

15. Wariishi H, Valli K and Gold MH (1992) Manganese(II) Oxidation by Manganese Peroxidase from the Basidiomycete Phanerochaete chrysosporium. Kinetic mechanism and role of Chelators. J Biol Chem 267(33):23688-95.

16. Conesa A, Götz S, García-Gómez JM, Terol J, Talón M and Robles M (2005) Blast2GO: a universal tool for annotation, visualization and analysis in functional genomics research. Bioinformatics 21(18):3674-6.

17. Chen TW, Gan RC, Fang YK, Chien KY, Liao WC, Chen CC, Wu TH, Chang IY, Yang C, Huang PJ, Yeh YM, Chiu CH, Huang TW and Tang P (2017) FunctionAnnotator, a versatile and efficient web tool for non-model organism annotation. Sci Rep 7(1):10430.

18. Moriya Y, Itoh M, Okuda S, Yoshizawa AC and Kanehisa M (2007) KAAS: an automatic genome annotation and pathway reconstruction server. Nucleic Acids Res 35: W182-5. 
19. Zhang H, Yohe T, Huang L, Entwistle S, Wu P, Yang Z, Busk PK, Xu Y and Yin Y (2018) dbCAN2: a meta server for automated carbohydrate-active enzyme annotation. Nucleic Acids Res 46(W1):W95W101.

20. Barrett K, Lange L(2019) Peptide-based functional annotation of carbohydrate-active enzymes by conserved unique peptide patterns (CUPP). Biotechnol Biofuels 12, 102.

21. Strasser K, McDonnell E, Nyaga C, Wu M, Wu S, Almeida H, Meurs MJ, Kosseim L, Powlowski J, Butler $G$ and Tsang A (2015) mycoCLAP, the database for characterized lignocellulose-active proteins of fungal origin:resource and text mining curation support. Database (Oxford): bav008.

22. Stanke $M$ and Morgenstern B (2005) AUGUSTUS: a web server for gene prediction in eukaryotes that allows user-defined constraints. Nucleic Acids Res 33:W465-7.

23. Solovyev V, Kosarev P, Seledsov I and Vorobyev D (2006) Automatic annotation of eukaryotic genes, pseudogenes and promoters. Genome Biol: 10.1-10.12.

24. Alfredo J, Otto M, Dimitrios F, Beatriz O, Elisabet S, Daniel L, Karen N, Tuomo N, Karl-Henrik L, Leif R, David S. Hibbett (2017) A revised family-level classification of the Polyporales (Basidiomycota). Fungal Biol 121(9) 798-824.

25. Andres RC (2017) Transposable elements in basidiomycete fungi dynamics and impact on genome architecture and transcriptional profiles, PhD thesis, public university of Navaraa.

26. Lee J, Godon C, Lagniel G, Spector D, Garin J, Labarre J and Toledano MB (1999) Yap1 and Skn7 Control Two Specialized Oxidative Stress Response Regulons in Yeast. J Biol Chem 274: 16040.

27. Ferreira P, Carro J, Serrano A and Martínez AT (2015) A survey of genes encoding H2O2-producing GMC oxidoreductases in 10 Polyporales genomes. Mycologia 107(6):1105-19.

28. Crešnar B and Petrič S (2011) Cytochrome P450 enzymes in the fungal kingdom. Biochim Biophys Acta 1814(1):29-35.

29. Floudas D1, Binder M, Riley R, Barry K, et al. (2012) The Paleozoic origin of enzymatic lignin decomposition reconstructed from 31 fungal genomes. Science 336:1715-1719.

30. Pollegioni L, Tonin F and Rosini, E. (2015) Lignin-degrading enzymes. FEBS J, 282: 1190-1213.

31. Eswaramoorthy S, Bonanno JB, Burley SK and Swaminathan S (2006) Mechanism of action of a flavin containing monooxygenase. Proc Natl Acad Sci U S A 103(26):9832-7.

32. Brace JL, Vanderweele DJ, Rudin CM (2005) Svf1 inhibits reactive oxygen species generation and promotes survival under conditions of oxidative stress in Saccharomyces cerevisiae. Yeast 22(8):641-52.

33. Baldrian P and Valásková V (2008) Degradation of cellulose by basidiomycetous fungi. FEMS Microbiol Rev 32(3): 501-521.

34. van den Brink J, de Vries RP (2011) Fungal enzyme sets for plant polysaccharide degradation. Appl Microbiol Biotechnol 91(6):1477-92.

35. Lombard V, Golaconda Ramulu H, Drula E, Coutinho PM, Henrissat B (2014) The Carbohydrate-active enzymes database (CAZy) in 2013. Nucleic Acids Res 42:D490-D495. 
36. Palmieri G, Giardina P, Bianco C, Fontanella B, Sannia G. (2000) Copper induction of laccase isoenzymes in the ligninolytic fungus Pleurotus ostreatus. Appl Environ Microbiol 66(3):920-4.

37. Kumar SV, Phale PS, Durani S and Wangikar PP (2003) Combined sequence and structure analysis of the fungal laccase family. Biotechnol Bioeng 83: 386-394.

38. Fernandez-Fueyo E, Ruiz-Duen as FJ, Ferreira P, Floudas D, Hibbett DS, et al. (2012) A Comparative genomics of Ceriporiopsis subvermispora and Phanerochaete chrysosporium provide insight into selective ligninolysis. Proc Natl Acad Sci USA 109: 5458-5463.

39. Jeffries TW, Choi S, Kirk TK. (1981) Nutritional regulation of lignin degradation by Phanerochaete chrysosporium. Appl Environ Microbiol 42: 290-296.

40. Janusz G, Kucharzyk KH, Pawlik A, Staszczak M and Paszczynski AJ (2013) Fungal laccase, manganese peroxidase and lignin peroxidase: Gene expression and regulation. Enzyme Microb Technol 52(1):1-12.

41. Yakovlev IA, Hietala AM, Courty PE, Lundell T, Solheim H and Fossdal CG (2013) Genes associated with lignin degradation in the polyphagous white-rot pathogen Heterobasidion irregulare show substrate-specific regulation. Fungal Genet Biol 56:17-24.

42. Rohr CO, Levin LN, Mentaberry AN, Wirth SA (2013) A First Insight into Pycnoporus sanguineus BAFC 2126 Transcriptome. PLoS One 8(12): e81033.

43. Hori C, Gaskell J, Igarashi K, Kersten P, Mozuch M, Samejima M and Cullen D (2014) Temporal Alterations in the Secretome of the Selective Ligninolytic Fungus Ceriporiopsis subvermispora during Growth on Aspen Wood Reveal This Organism's Strategy for Degrading Lignocellulose. Appl Environ Microbiol 80(7):2062-70.

44. Kameshwar AK and Qin W (2017) Metadata Analysis of Phanerochaete chrysosporium Gene Expression Data Identified Common CAZymes Encoding Gene Expression Profiles Involved in Cellulose and Hemicellulose Degradation. Int J Biol Sci 13(1): 85-99.

\section{Figures}




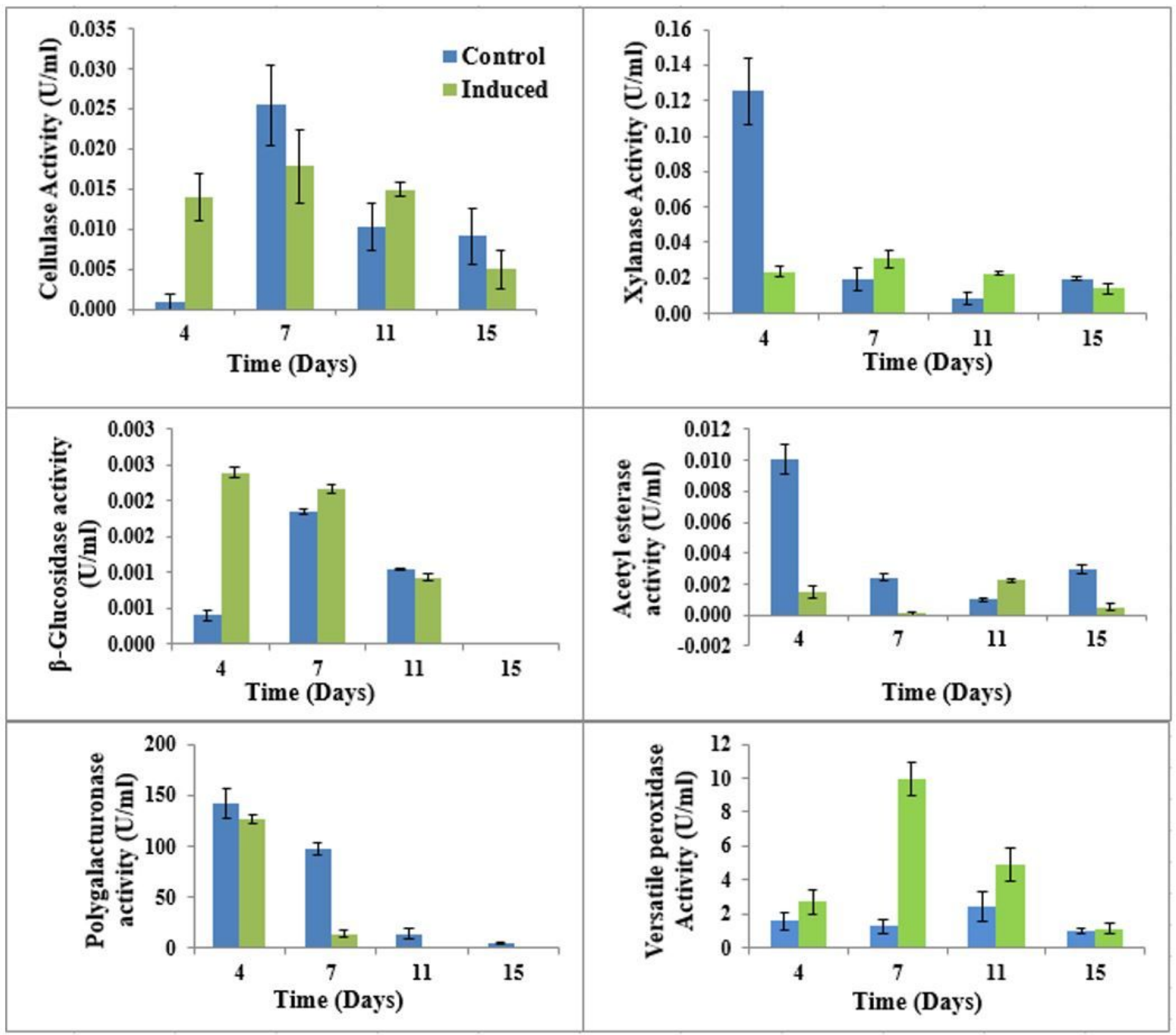

Figure 1

Biochemical analysis of few biomass degrading enzymes in the culture supernatant of L.squarrosulus 


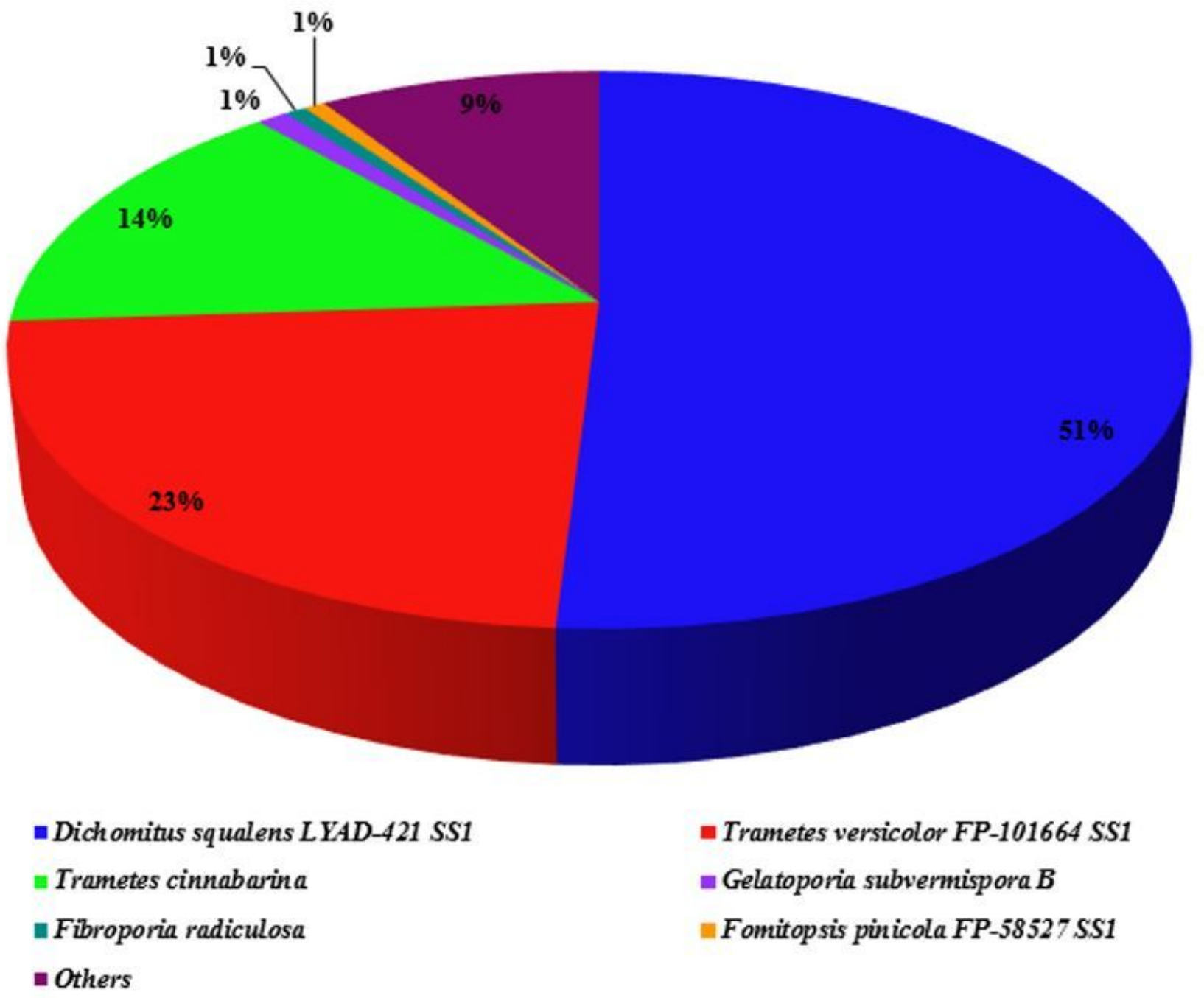

Figure 2

Taxonomic distribution of L.squarrosulus nucleotidesequences at species level. 


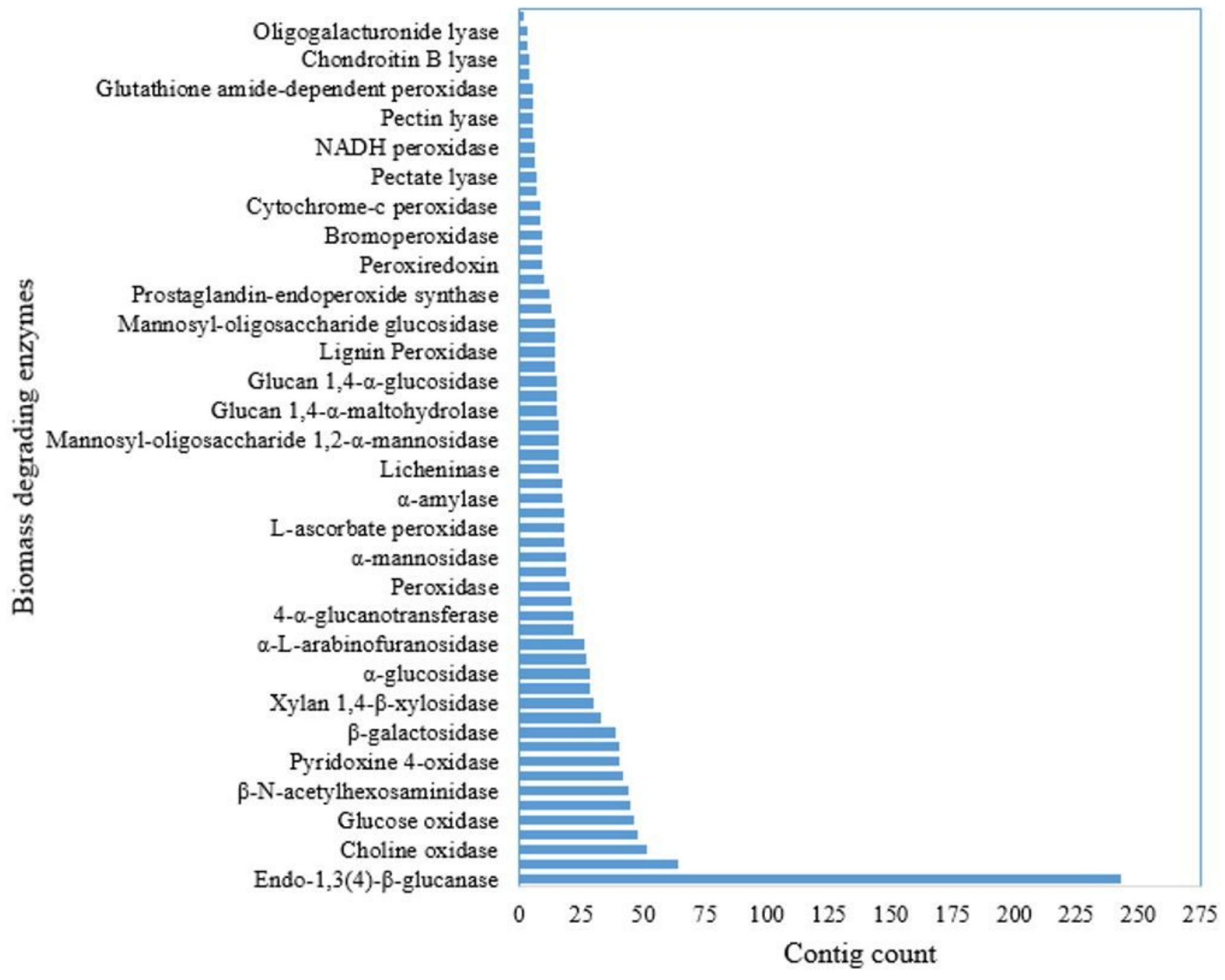

Figure 3

Putative biomass degrading enzymes of Lentinus squarrosulus 


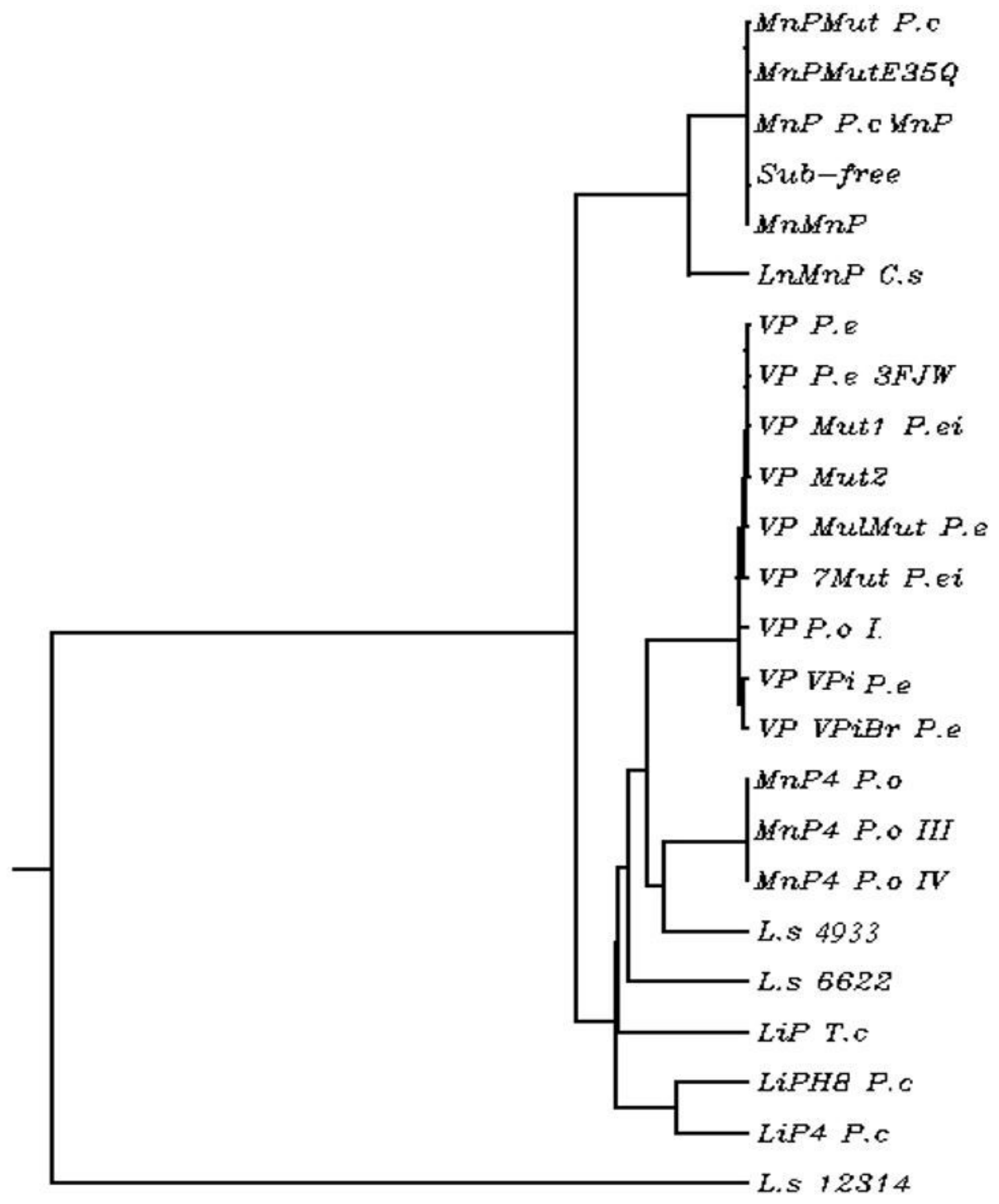

Figure 4

Multiple sequence comparison of Ligninolytic peroxidases with L.squarrosulus putative versatile peroxidase sequences [P.c - Phanerochaete chrysosporium; C.s - Ceriporiopsis subvermispora; P.ePleurotus eryngii; P.o- Pleurotus ostreatus; T.c - Trametes cervina; L.s - Lentinus squarrosulus] 


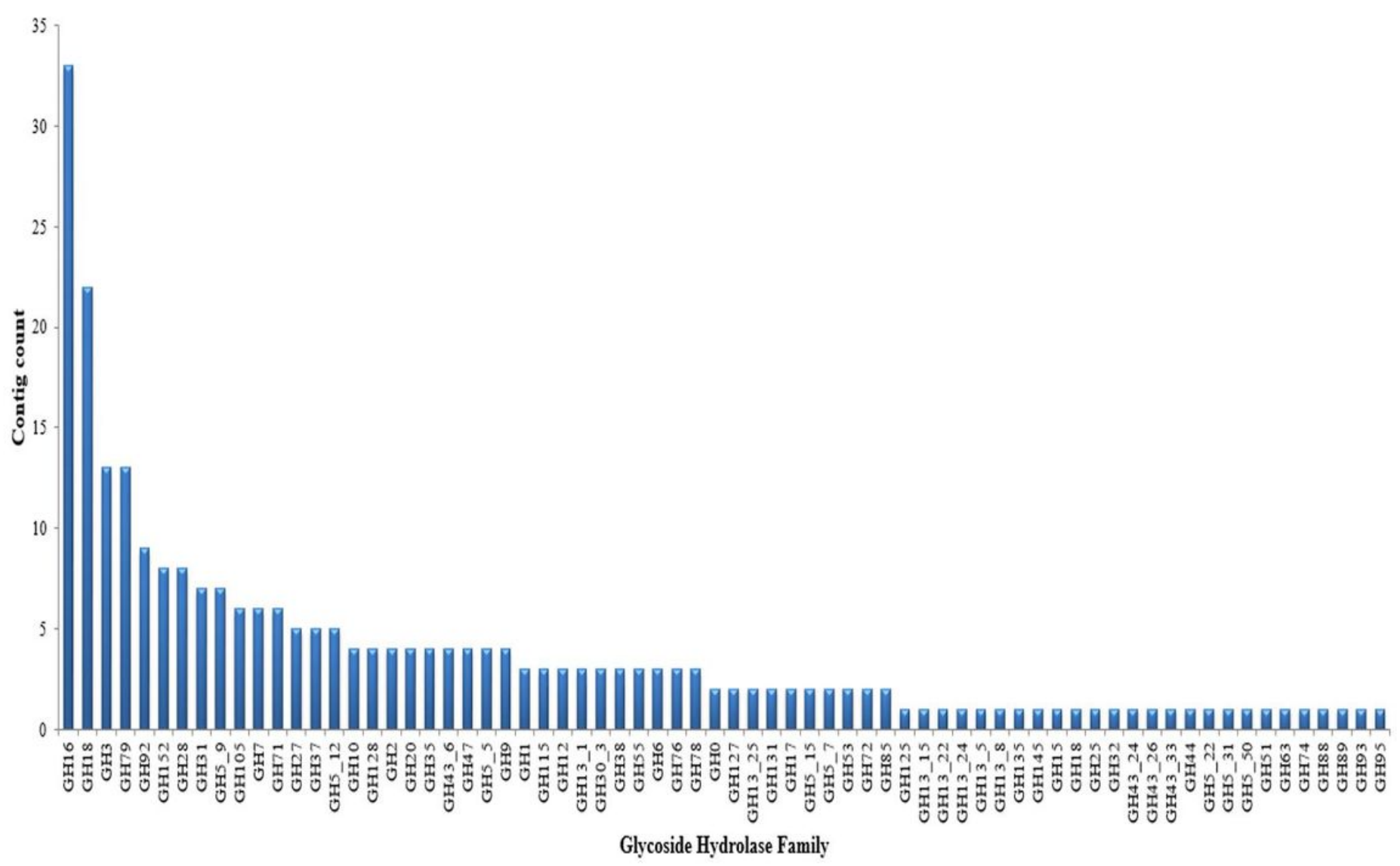

Figure 5

Distribution of Glycoside hydrolases $(\mathrm{GH})$ in the transcriptome predicted based on CAZyme database. 

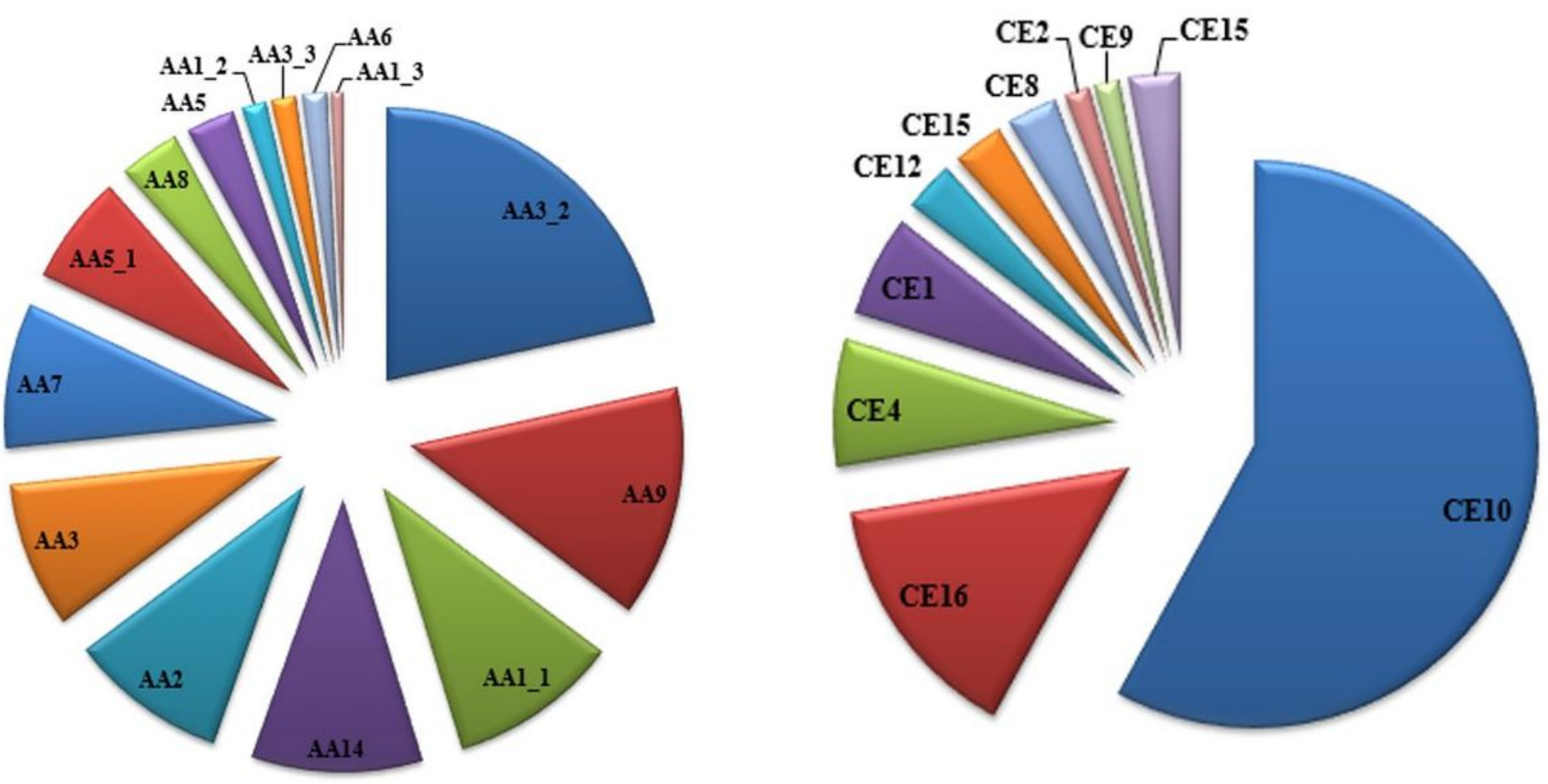

Figure 6

Distribution of Auxiliary activities (AA) enzymes and carbohydrate esterases (CE) in the transcriptome predicted based on CAZyme database. 


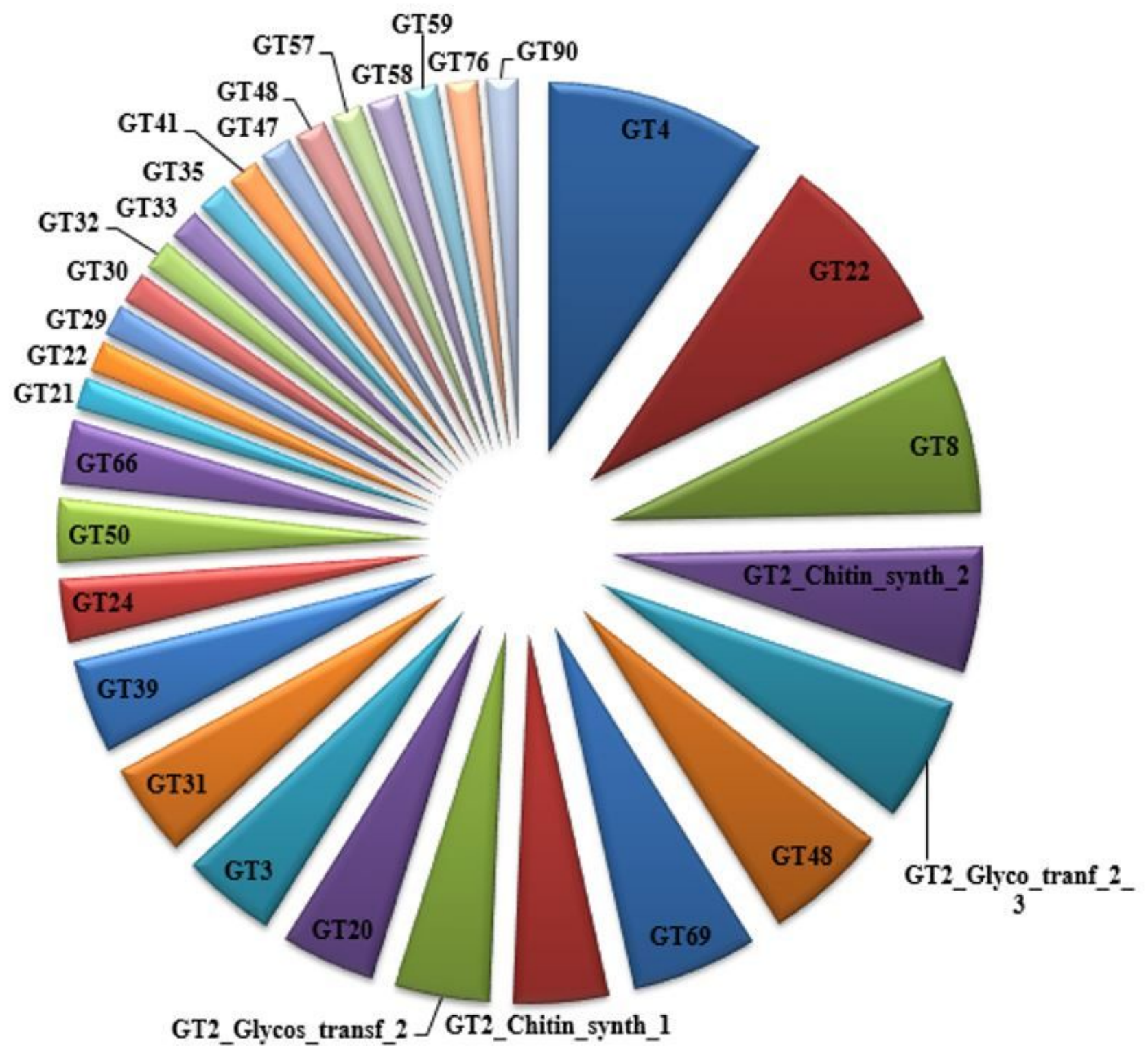

Figure 7

Distribution of glycosyl transferases (GT) in the transcriptome predicted based on CAZyme database.

\section{Supplementary Files}

This is a list of supplementary files associated with this preprint. Click to download.

- Legendsforsupplementarytables.xls

- 1LsquarrosulusGODatamodified.xIs 
- 2LsquarrosulusDomainHits.xls

- 3LsquarrosulusAnnotationtable.xls

- 4KOannotation.xls

- 5EnzymeAnnotation.xls 